Journal of Law \& Social Studies (JLSS)

Volume 1, Issue 1, pp 13-26

www.advancelrf.org

\title{
Mediation of firm innovativeness and moderation of environment turbulence on entrepreneurial orientation and firm performance
}

\author{
Khawar Naheed (Corresponding Author) \\ Department of Commerce. Bahauddin Zakariya University Multan \\ khawarnaheed@bzu.edu.pk \\ Muhammad Aamir (Research Scholar) \\ Department of Commerce. Bahauddin Zakariya University Multan \\ aamir.tayyab011@gmail.com \\ Naveed Ahmad (Research Scholar) \\ Institute of Industrial Revolution 4.0, Universiti Kebangsaan Malaysia. \\ naveedqadri@siswa.ukm.edu.my
}

\begin{abstract}
The objectives of this study are to examine; the direct effect of entrepreneurial orientation, firm innovativeness on firm performance; the indirect effect of firm innovativeness between entrepreneurial orientation and firm performance; and the moderating role of market turbulence between firm innovativeness and firm performance. Using a quantitative approach, this study has collected data through a survey questionnaire from a sample of 300 Pakistani IT-based SMEs operating in South Punjab, Pakistan. The data was analyzed in SPSS and PLS-SEM software. The results revealed a significant direct positive impact of entrepreneurial orientation and firm innovativeness on business performance. The result also confirmed the partial mediation of firm innovativeness between entrepreneurial orientation and business performance. The moderating role of environmental turbulence indicated that SMEs owners' market and technological environment decrease the firm performance. Overall, these findings highlighted the importance of entrepreneurial orientation, firm innovativeness, market turbulence and technological competition jointly influence the direction and strength of the SMEs performance. This study enhanced firm performance and innovation-based research by identifying the configurationally market conditions that augment or limit the value of firm innovativeness. Besides, the study has highlighted the role of environmental turbulence on firm performance as the studies on this issue is scarce.
\end{abstract}

Keywords: Entrepreneurial Orientation, Firm Innovativeness, Market Turbulence, Firm Performance.

\subsection{Introduction}

Entrepreneurial orientation (EO) dominant impact on firm's success and its sustainable performance (Covin \& Miller, 2014; Shan, Song, \& Ju, 2016; William, 2016). Firm Performance (FP) is a process of achieving goals and strategic objectives that are related to market growth (Henard \& Szymanski, 2001). Researchers have found many antecedents that can increase the performance and productivity of organizations such as environmental hostility, market growth, innovation ambidexterity, leadership style, knowledge creation, entrepreneurial orientation, Firm Innovativeness (FI), market turbulence and Environmental Turbulence (ET).

Among the antecedents of FP, EO explained the process of new and distinctive performance followed by entrepreneurs that allows organizations to enter in innovative market (Kraus, Rigtering, Hughes, \& Hosman, 2012; Wang \& Yen, 
2012). Moreover, EO provides the basis for entrepreneurial strategic decision making and has evoked significant attention of scholar. Researchers have explained EO along with its four dimensions (Miller, 1983).

Another key antecedent of FP is FI that has obtained attention in the firm structure as it influences the innovative capability of the firm (Hurley \& Hult, 1998; Nasution, Mavondo, Matanda, \& Ndubisi, 2011). FI explained as the process of an organization directness (openness) to accept unique and innovative ideas as part of its culture (Hult, Hurley, \& Knight, 2004; Menguc \& Auh, 2006). With time, FI reflects the image of a firm to utilize its current resources and adopts innovative means to contribute to the development of innovative products and services (Calantone, Garcia, \& Dröge, 2003). The culture of a firm is also reflected by motivating its employees to do something unique that explained its innovative capabilities (Hult \& Ketchen, 2001). Adopting Resource Based View (RBV) that explains firm innovative capabilities to sustain competitiveness that can attain through the innovative process (Kraaijenbrink, Spender, \& Groen, 2010; Miller \& Shamsie, 1996). This relationship is evidenced through the study of Damanpour, (1991) that has confirmed the significant influence of FI and EO on the firm performance.

Extant literature argued that the organizational environment affects its provocativeness about the opportunities and limitations related to the external environment regarding firm innovation and performance ET has evoked the researcher's attention because of the importance of firm performance (Barney, Ketchen, \& Wright, 2011; Zahra \& Wright, 2011). ET denotes the technology and market changes in the external environment of a firm and can strengthen or weaken the firm performance.

The performance of the firm has an impact on SMEs overall growth. These factors of firm failure occur when there is a lack of EO, FI and considering the role of ET. Researchers have studied the effect of the antecedents on FP in developed countries, however, there is need to research these important antecedents including EO (Tsai \& Yang, 2014), FI (Mason, Floreani, (Miani, Beltrame, \& Cappelletto, 2015) and ET (Tang \& Tang, 2012) in other cultures like Pakistan. SMEs of Pakistan contribute $90 \%$ of all the enterprises and it has a $40 \%$ share contribution in the annual GDP of Pakistan (SMEDA; State bank of Pakistan. Conversely, Pakistani SMEs facade many issues to start their ventures particularly absence of managerial capabilities in strategic planning and execution including glance over market, environment, technology advancement, and absence of R\&D (SMEDA; State bank of Pakistan). This study helps SMEs in solving these problems by examining the role of EO, FI and ET that can increase SME's performance in Pakistan.

The current study has the following research objectives; it examines the relationship of EO and FP; FI and FP; mediation of FI between EO and FP, and moderation of ET on FP.

\subsection{Literature Review and Hypothesis Development}

\section{Firm Performance}

Firm performance explained the survival of the firm regarding its success or failure (Yildiz, 2010). FP explains the achievement of organizational goals and its objectives that has impact on profit and growth of firm (Henard \& 
Szymanski, 2001). Many antecedents can increase the FP such as environmental hostility, market growth, innovation ambidexterity, leadership style, knowledge creation, Entrepreneurial Orientation (EO), Firm Innovativeness (FI) and Environmental Turbulence (Bedeian \& Wren, 2009; Covin \& Lumpkin, 2011; De Clercq, Dimov, \& Thongpapanl, 2013; Northouse, 2015; Zhang, Edgar, Geare, \& O'Kane, 2016).

\section{Entrepreneurial Orientation and Firm Performance}

EO is relatively developed in recent studies of entrepreneurship (e.g., Covin \& Miller, 2014; William John Wales, 2016). EO explains the strategic decision making process that helps firms to take actions (Wiklund \& Shepherd, 2003). EO is the process of innovative unique practices and processes followed by entrepreneurial behaviors that allow firms to enter into the innovative or traditional markets (Eshima \& Anderson, 2016; Lumpkin \& Dess, 1996; Wales, Parida, \& Patel, 2013; Walter et al., 2006; Wiklund \& Shepherd, 2003). EO helps for looking new opportunities and development of innovative products or services that can increase FP (Bhuian, Menguc, \& Bell, 2005; Hurley, Hult, \& Knight, 2005; Wiklund \& Shepherd, 2003).

The study of Wang \& Yen, (2012) found a positive relationship between EO and FP and recommended that EO is more useful as a multidimensional construct, not as a single-dimensional construct. Based on the recommendation of the above study, this study considers the EO dimensions conceptualized by the study of Lumpkin \& Dess, (1996, 2001) and followed by the other studies (Miller, 1983, 2011; Stam \& Elfring, 2008).

Risk-taking is an organization inclination to initiate bold decisions regarding the uncertain environment (Rauch et al., 2009). Pro-activeness states the capacity to introduce innovative services, obtaining new opportunities and creating change to face the future demand in the competition environment (Lumpkin \& Dess, 2001). Aggressiveness in competition is capability of organization to link and distinguish from its competitors from strong unpleasant position and risk (Lumpkin \& Dess, 2005). "Autonomy refers to the process of independent behavior of leader and team toward achieving aimed goals and objectives without any limitation of the firm" (Li, Huang, \& Tsai, 2009).

There is empirical evidence about positive relationships of EO with FP (Al-Dhaafri, Al-Swidi, \& Yusoff, 2016; Dada \& Watson, 2013; Kemelgor, 2002; Kraus et al., 2012). Entrepreneurial orientation helps the organization to build up strategies and innovative approaches to take certain actions, decisions and solve problems to increase FP. Hence, the following hypothesis is proposed:

$\mathbf{H}_{1}$ : EO has positive relationship with FP.

\section{Entrepreneurial Orientation and Firm Innovativeness}

EO denotes the process of "innovative practices, processes and decision making" that lead toward entering into traditional market with innovative services (Eshima \& Anderson, 2016; William, Wales, Parida, et al., 2013). An entrepreneur as decision maker has liability to create new ideas and innovation because he or she is always looking for new opportunities and development in process and strategies in his firm so, EO is related to FI (Hult et al., 2004). FI refers to the firm's openness to innovative ideas and the development of innovative products that reflects the firm trend toward innovativeness (Augusto \& Coelho, 2009; Hurley \& Hult, 1998; Nasution et al., 2011). The positive relationship found between EO and FI (Hult et al., 2004). The study of Tsai \& Yang, (2014) suggested further research in other settings. Based on above argument, following hypotheses is suggested:

$\mathbf{H}_{2}$ : EO has a positive relationship with FI. 


\section{Mediation of Firm Innovativeness}

FI is a process of firm supportive and open culture to innovate and develop new products that showed the trend of innovative firm culture (Augusto \& Coelho, 2009; Hult \& Ketchen, 2001; Marcati et al., 2008; Menguc \& Auh, 2006; Nasution et al., 2011; Tajeddini, Trueman, \& Larsen, 2006). Conferring to this definition, FI provides confidence to its employees to involve in create ideas and also search for new problem solving approaches (Chatman \& Cha, 2003). Previous researchers believe that a firm's innovation comes from the FI (Han, Kim, \& Srivastava, 1998; Kirca, Jayachandran, \& Bearden, 2005), because "a highly innovative product does not automatically imply highly innovative firms" (Garcia \& Calantone, 2002). Innovation has an important factor in firm's innovativeness (Menguc $\&$ Auh, 2006), for that reason an innovative firm always gave confidence to its employees to do experimentation by some creative thoughts and procedures (Menguc \& Auh, 2006) and to produce incredible unique products (Luk et al., 2008). Innovative firms use the labor and capital markets to get the possible inventions in their firm (Tellis, Prabhu, $\&$ Chandy, 2009). Further in terms, firm innovativeness stimulates innovative activities aimed at producing creative tangible and intangible products (Dibrell, Craig, \& Hansen, 2011; Hurley \& Hult, 1998). The recourse based view of the firm (Barney, 1991; Barney et al., 2001); innovative firms have the resources to help the firms move toward competitive benefit and to improved performance (Barney et al., 2011; Hurley \& Hult, 1998; Menguc \& Auh, 2006). In this study, RBV explained these constructs because the firm can sustain competitive lead with their innovative process and product (Kraaijenbrink et al., 2010; Miller \& Shamsie, 1996) and explores the relationship between these two variables (FI and FP) because it influences the firm growth and performance ( Henard \& Szymanski, 2001).

Firm's innovativeness helps the firm to increase innovations and new ideas; it can increase the firm's competitiveness and increase the performance. Extant studies have evidenced positive association of FI and FP (Tsai \& Yang, 2013, 2014). Furthermore, the previous study also found positive mediating role FI between EO and FP (Hult et al., 2004). The firms with high innovation can get more performance rather than the firms are having low innovation. Therefore, this research proposes the following hypothesis:

H3: FI has a positive relationship with FP.

H4: FI has a mediating effect between EO and FP.

\section{Moderating Effect}

Environmental turbulence states uncertain variations in the external environment (market and technological), which is based on contingency theory (Barrows \& Neely, 2011; Danneels \& Sethi, 2011; Kipley et al., 2012). Environmental contingency theory (ECT) recommends that if a firm wants success so it should adapt the situation of its external environment (Hatch, 2006). In a particular industry environment, environmental contingencies may create opportunities and constraints for innovation (Tidd, 2001). There are two major contingencies such as technological and market orientations (Danneels \& Sethi, 2011). Within an industry, technological and market changes often occur (Calantone et al., 2003). Technological change is a speed of change in technology within an industry (Tsai, Chou, \& Kuo, 2008). Market change is a degree of change in customer choices (Olson et al. 2005). ET is a serious issue for organization survival. ET explains the degree of unexpected change. Thus, the greater the unexpected change, the more it has the worst effect on organization performance. A previous study has shown the significant impact of ET on firm performance ( e.g., Tsai \& Yang, 2014). Therefore, this study proposes that: 
H5: ET moderates between FI and FP.

Conceptual Framework

Entrepreneurial orientation

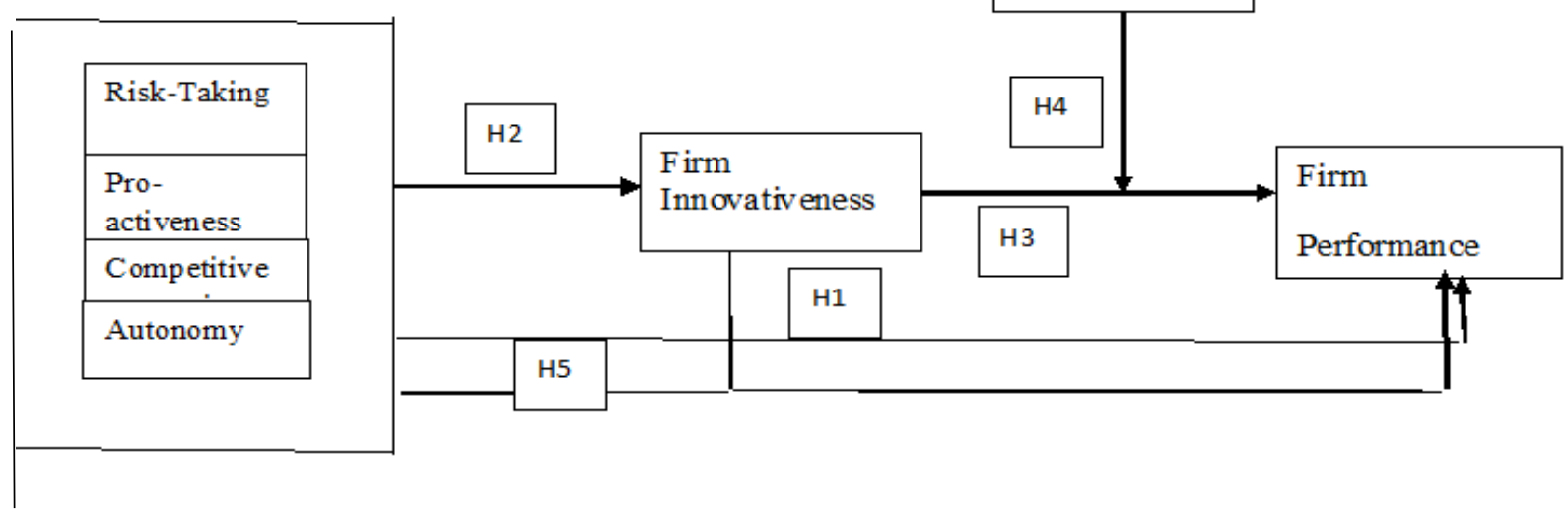

\subsection{Research methodology}

This study used quantitative approach and collected data through survey questionnaire using convenient sampling from 300 owners and managers working in information technology based SMEs operating in Punjab, Pakistan. Quantitative approach is most appropriate as the study used positivists method by using empirical evidence based data, Moreover, the study has confirmed the model. As the study collected data about the firm innovativeness, therefore only IT based firms were focused because these firms can only survive on innovative approach.

The current study has collected data through personal visit to the firm's managers at all levels. Face to face data collection has more positive response as compare to email and postal data collection. The researcher has collected all the distributed questionnaires with $100 \%$ response rate.

The current study used well established adopted scales from previous literature. This study measured FP by asking four measures; (1) return on assets (2) sales growth (3) market share growth (4) overall FP that was adopted from the study of Tsai \& Yang, (2013, 2014). EO was measured with its four dimensions "pro-activeness, risk-taking, competitive aggressiveness and autonomy". This study adopted measure for FI and ET from the study of Tsai \& Yang (2014). This study used SPSS 24.0 for preliminary analysis and Partial Least Square (PLS-SEM) for main analysis. Hair et al., (2014) has suggested PLS for moderated- mediated model. This study used ET as a moderator and FI as a mediator. The current reported measurement and structural model results.

\section{Data Analysis and Discussion}

\subsection{Main Analysis}

This part is divided into two segments. The first segment reported outer model results. The second segment reported inner model results found about the hypothesized relationships, significance and coefficient of determination $\left(\mathrm{R}^{2}\right)$.

\subsubsection{Measurement Model}

The Constructs' level reliability is judged through "Cronbach's alpha, composite reliability and validity". Validity is measured through discriminant validity (AVE) AND convergent validity (cross-loading and Fonell Larcker Criterion) (Fornell larcker, 1981). CR explained internal consistency (hair et al., 2014), and Cronbach's alpa. This study findings 
are according to rules of thumb. The value for composite reliability is $\geq 0.7$. In the present study it is ranging under 0.840-0.882. Which indicate that results are acceptable level.

Table 4.1 Measurement Model Results

\begin{tabular}{|c|c|c|c|c|}
\hline Constructs & $\begin{array}{l}\text { Factor } \\
\text { loadings }\end{array}$ & Cronbach's Alpha & CR & AVE \\
\hline EO & & .852 & .882 & .516 \\
\hline EO1 & 0.662 & & & \\
\hline $\mathrm{EO} 2$ & 0.656 & & & \\
\hline EO3 & 0.675 & & & \\
\hline EO4 & 0.652 & & & \\
\hline EO5 & 0.632 & & & \\
\hline EO6 & 0.631 & & & \\
\hline EO7 & 0.643 & & & \\
\hline EO8 & 0.643 & & & \\
\hline EO9 & 0.683 & & & \\
\hline EO10 & 0.661 & & & \\
\hline ET & & .814 & .870 & .573 \\
\hline ET1 & 0.725 & & & \\
\hline ET2 & 0.785 & & & \\
\hline ET3 & 0.787 & & & \\
\hline ET4 & 0.755 & & & \\
\hline ET5 & 0.731 & & & \\
\hline FI & & .762 & .840 & .512 \\
\hline FI1 & 0.702 & & & \\
\hline FI2 & 0.729 & & & \\
\hline FI3 & 0.741 & & & \\
\hline FI5 & 0.683 & & & \\
\hline FI6 & 0.722 & & & \\
\hline FP & & .769 & .844 & .520 \\
\hline FP1 & 0.761 & & & \\
\hline FP2 & 0.773 & & & \\
\hline FP3 & 0.714 & & & \\
\hline FP4 & 0.669 & & & \\
\hline FP5 & 0.681 & & & \\
\hline
\end{tabular}

EO= Entrepreneurial Orientation, ET= Environmental turbulence, FI= Firm Innovativeness FP= Firm Performance, average variance extracted (AVE), Composite Reliability (CR)

Table 4.1 reported about convergent validity (factor loadings) and convergent validity. The results supported the criteria as outer loading of each item is higher $>0.60$ and AVE is $>0.40$ for constructs. Results reported in the above table showed that factors loadings values for EO, FI, ET and FP are greater than 0.60 and values of AVE are greater than 0.40. Put succinctly, an AVE of 0.50 showed that "the construct explains more than half of the variance of its indicators". 
Table 4.1 showed obtained results for Cronbach alpha that represented the composite reliability Hair et al., (2014) suggested "composite reliability analysis" to check the internal consistency as it shows the best results of internal consistency reliability. The result for composite reliability values meet the criteria as values for EO, FI, ET and FP are above 0.6o which fulfilled the suggested criteria by (Hair et al., 2011; Nunnally, 1978).

\section{Discriminant validity}

The second step is to assess the validity is discriminate validity. The discriminant validity is assessed through FornallLarcker criterion (Fonell Larcker, 1981). In Fonrall Larcker criteria, “each construct must be high squared AVE then others" (Fonrell Larcker 1981). Below table 4.2 shows the Fornell Larcker criterion. The results supported the suggested criteria.

Table 4.2 Fonrell Larcker Criterion

\begin{tabular}{|l|l|l|l|l|}
\hline & EO & ET & FI & FP \\
\hline EO & $\mathbf{0 . 6 5 4}$ & & & \\
\hline FI & 0.662 & $\mathbf{0 . 7 5 7}$ & & \\
\hline FP & 0.677 & 0.578 & $\mathbf{0 . 7 1 6}$ & \\
\hline
\end{tabular}

$\mathrm{EO}=$ Entrepreneurial Orientation, ET= Environmental turbulence, FI= Firm Innovativeness FP= Firm Performance

\subsection{Inner model Evaluation}

The inner model evaluates the relationships and significance of the variables under investigation. Inner model is assessed through Coefficient of determination $\left(\mathrm{R}^{2}\right)$ and Path Coefficients $(\beta)$

\section{Coefficient of Determination $\left(\mathbf{R}^{2}\right)$}

$\mathrm{R}^{2}$ measures the "predictive accuracy" of the structural model and predict how much independent variables combined effect on the dependent variable. Result reported in Table 4.4 showed moderate to week predictive accuracy of FI and FP.

Table 4.4

\begin{tabular}{|l|l|}
\hline Latent Variables & $\mathbf{R}^{\mathbf{2}}$ \\
\hline FI & .458 \\
\hline FP & .484 \\
\hline
\end{tabular}

Note: FI= Firm innovativeness, FP= Firm Performance

Table 4.5 Structural Model Results

\begin{tabular}{|l|l|l|l|}
\hline & $\begin{array}{l}\text { Beta } \\
\text { Coefficient }\end{array}$ & T-Statistics & P-Values \\
\hline EO -> FI & .677 & 23.767 & .000 \\
\hline EO -> FP & .263 & 4.672 & .000 \\
\hline ET -> FP & .363 & 6.495 & .000 \\
\hline FI -> FP & .134 & 2.319 & .020 \\
\hline
\end{tabular}




\section{Moderating Effect 1 -> FP}

\begin{tabular}{l|l}
-.047 & 1.758
\end{tabular} .079

EO= Entrepreneurial Orientation, ET= Environmental turbulence, FI= Firm Innovativeness FP= Firm Performance

Table 4.5 showed the results of the path coefficient and significance of hypothesized relationships. The results showed that the hypothesized relationship is significantly related to each other. Values of EO- $>$ FI $(\beta=0.677, t=4.672$, p>.01.000) showed that EO has a positive and significant relationship with FI. ET- $>$ FP values $(\beta=0.261, t=4.672$, $\mathrm{p}>.01)$ that showed ET has significant positive relationship with FP. ET- $>$ FP values are $(\beta=0.360, t=6.495, p>0.01)$ showed a significant positive relationship between ET and FP. Values for FI -> FP showed a significant positive relationship as the values are $(\beta=0.130, \mathrm{t}=2.319, \mathrm{p}>0.020)$. The results of the moderating hypothesis showed a significant negative interaction effect as the values are $(\beta=-0.047, t=1.758, p>0.079)$. It means that entrepreneurial turbulence moderate between FO and FP.

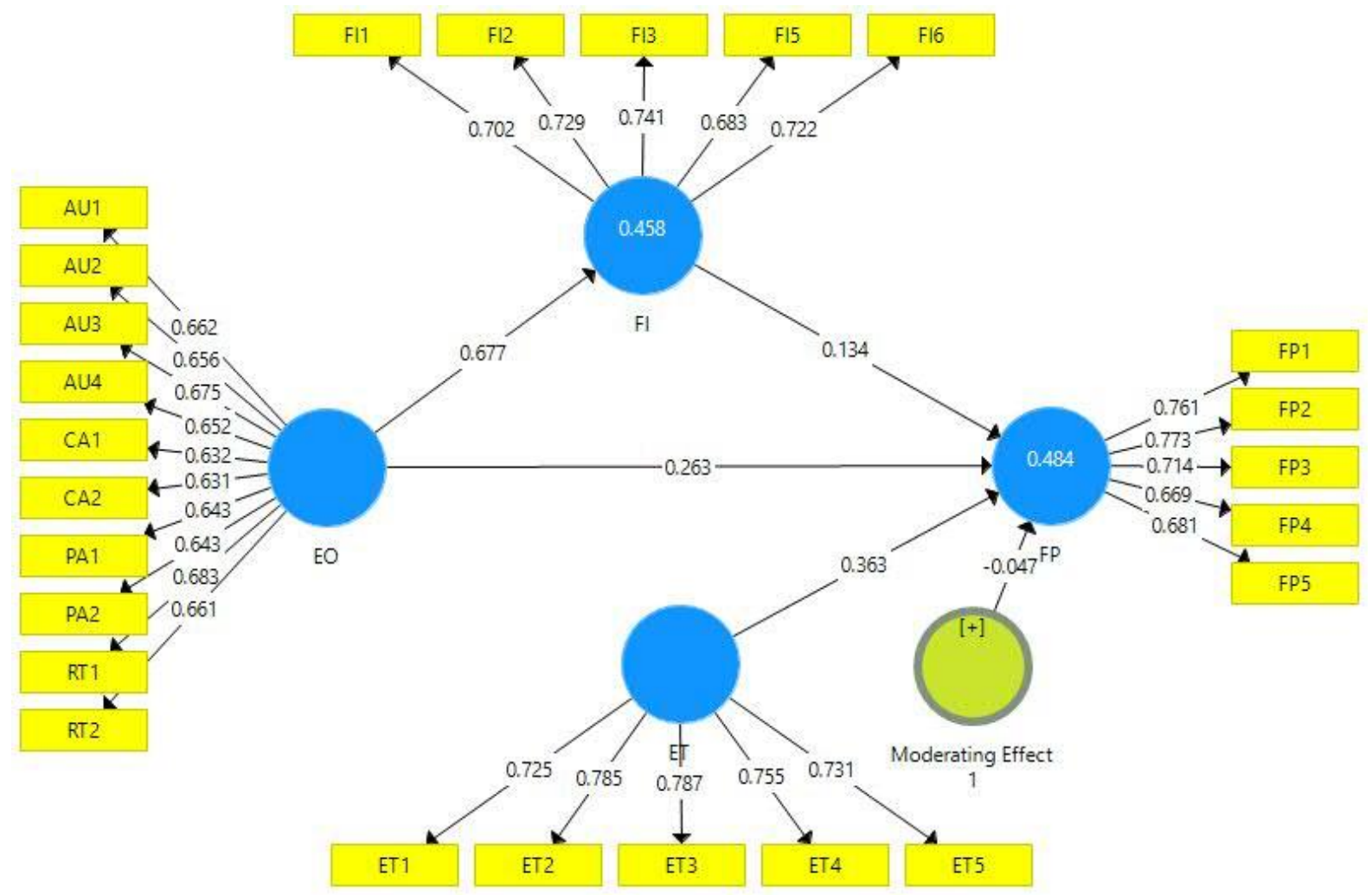

Figure 4.1 Structural Model With moderation

\section{Mediation Analysis}

Mediation is a process of involvement between two variables between independent and dependent. "It like independent variable $\mathrm{X}$ and dependent variables $\mathrm{Y}$ in which $\mathrm{M}$ involve as a mediator".

Table 4.6 Mediation Analysis

\begin{tabular}{|l|l|l|l|l|}
\hline Relationship & Indirect effect & Total effect & VAF & Result \\
\hline EO->FI->FP & .088 & .349 & .2522 & Partial mediation \\
\hline
\end{tabular}


In Table 4.6 the results for mediation analysis of current are reported. The above table showed the results of a simple mediation analysis. Variance Accounted Factor (VAF) found in the current model are greater than $20 \%$ that showed a partial mediation of FI between EO and FP. Rules of thumb for mediation are that; VAF value is less than 20\% indicate no mediation. In the current study the value is greater than $20 \%$ supported partial mediation.

Table 4.7 Hypothesis Results

\begin{tabular}{|l|l|}
\hline Hypotheses & Research Finding \\
\hline $\mathrm{H}_{1}$ & Accepted $(\mathrm{t}=4.672, \mathrm{p}<=0.00)$ \\
\hline $\mathrm{H}_{2}$ & Accepted $(\mathrm{t}=23.767, \mathrm{p}<=0.00)$ \\
\hline $\mathrm{H}_{3}$ & Accepted $(\mathrm{t}=2.319, \mathrm{p}<=0.00)$ \\
\hline $\mathrm{H} 4$ & Accepted $(\mathrm{t}=1.758, \mathrm{p}=0.078)$ \\
\hline
\end{tabular}

Table 4.7 showed the outcomes of proposed relationships in the current study. H1, H2, and H3 are found to have significant positive relationships while ET has negative interaction and a significant level greater than 0.05 but less than 0.10 supported.

\subsection{Discussion}

The objects of the current study are to examined; first, direct relationships among EO, FI, and FP; second, indirect relationships of FI; and moderating role of ET. The results of the current study provide valuable findings such as entrepreneurial orientation, firm innovativeness have significant positive link with the FP of SMEs. The FI has partial mediation between EO and FP. The ET has a negative but significant level of 7\%.

In general, the results of this study underlined that the top management need to focus on environmental factors that can enhance innovative culture to increase FP. Explicitly, MO and EO have a noteworthy affirmative effect on FI and FP. The findings regarding EO and FP is evidenced in previous studies (e.g., Soininen et al., 2012; Van Doorn et al., 2013). These studies have viewed EO is crucial for realizing greater organizational performance and have highlighted that EO is the firm special resources and capabilities that have worth in increasing FP. The results indicated that the reason for increasing SMEs performance is that they found new opportunities and develop innovative products or services. The unique behavior, processes, and practices are followed by the SMEs not only increase their innovative capacity but also increase their performance.

The result for $\mathrm{H} 2$ and $\mathrm{H} 3$ have evidenced noteworthy affirmative relationships between $\mathrm{EO}$ and FI with FP. The results for both hypotheses indicate that EO and FI are the significant antecedents that effect on the performance of SMEs. Accordingly, firms may influence the benefits accompanying with EO and innovation capabilities as a part of its innovative supportive culture that strengthen SMEs performance. The culture through providing a supportive environment that promotes and encourages innovative ideas as a part of innovation. The findings supported and suggested that EO is important in the progress and conservation of innovativeness, regardless of any other factor. 
The result for $\mathrm{H} 4$ the partial mediation of FI between EO and SMEs performance also supported. This showed that EO represents the abilities of (pro-activeness, aggressiveness, and initiative) that can drive management to start several new and unique (innovative) initiatives and these initiatives along with other factors leads to boost the performance of SMEs. Accordingly, EO is regarded as the trigger that flares up the performance through innovativeness.

The result for H5 showed that ET that are the uncertain changes due to external environment including market and technological changes decrease the SME's performance when measured as a moderator while it has a progressive influence as an antecedent of FP. The findings of this study do not contradict with result of Huang \& Tsai (2014) that have evidenced effect of technological turbulence on product performance. ET force organization to leave or survive in a competitive environment keeping into considering new capabilities and offering new products to increase its performance. The result indicated that SMEs are not responding to the market and technological factors, this may decrease the performance of the organization. FI is deliberated an effective management option to be well aware of the uncertain factors regarding maker and technology available to businesses in addressing the environmental issues that affect business performance adversely.

Generally, the complete analysis of the conceptualized model showed three main effects direct effect of EO, mediation of FI and moderation ET in measuring firm performance. Furthermore, there are all attributes combined for the use of environmental turbulence which is achieved by their market growth and giving some of the additional association of entrepreneurial orientation.

\section{Contribution of the Study}

This study has confirmed that firms are more valuable and useful in their performance with the support of entrepreneurial orientation, innovativeness. The findings point to several critical factors in the business performance of industrial firms. In the aggregate, little is known about the interrelationships among the integrative elements of MO, LO, and EO, their effect on SMEs innovativeness, and its subsequent FP. This study enriched the literature by concentrating on originators of IT-based SME's performance.

\section{Implication of the Study}

The result of the current study implies that interrelationships among the variables of interest are important for firms' sustainable competitive advantage. This study suggested to the managers that firm innovativeness is a key mediator between EO and FP. Looking to the future, the turbulence that characterizes many industries is likely to continue that is not being focused by many organizations. Under such conditions, organizations are advised to invest in developing their market, learning, and entrepreneurial orientations. Additionally, the management should plan and implement innovative activities within the framework of these antecedent constructs. A central message from the evidence provided is that possession of a strong learning orientation in the absence of organizational innovativeness is likely to be substantially less effective for allowing the firm to achieve its performance goals.

Decisions about the culture of SMEs should be considered by the management as top priority. Considering the importance of innovativeness in SMEs performance, it is the task of top level management to strategize and 
contrivance its culture that represents $\mathrm{MO}, \mathrm{LO}$, and EO. Furthermore, decisions regarding innovativeness tend to be taken by the marketing, R\&D and operations managers. Accordingly, to enhance SMEs discrete areas' performance, and structure with coordinated efforts to guarantee the innovative there is a need for further undertakings to get benefits from MO, LO, and EO. The findings of this study can improve management performance and decision making. This study expects that future studies can probes more on the effect of MO, EO and LO and their effect on diversified settings among SMEs in several sectors.

\section{Conclusion}

These study point-out important factors related to SMEs' performance particularly enriched the evidential support among the interrelationships of market orientation, firm innovativeness, and environmental turbulence through direct and subsequent effect on firm performance. So far, the support presented in this study suggests that such relationships need to be realized as these assist in providing sustainable performance. Particularly FI seems to be an important mediator in the inter-relationship among the constructs. For the future, the turbulence that embodies many aspects need to be critically focused by the SMEs particular. The result suggests that SMEs need to invest in developing their market, technology, innovation to enhance their performance. Additionally, the SMEs should strategically plan and execute not only innovative activities but also focus on scanning the unexpected market or technological advancement. A dominant result of this study evidenced that the existence of significant MO in the deficiency of FI less operative to achieve organizational goals particularly SMEs performance. The result realized the importance of FI for SMEs' performance, it is the top responsibility of management is to draft and execute innovative culture that considers MO and ET. Moreover, strategic management should decide about the innovative supportive initiatives including market and research. To increase SMEs' performance, it is very important to focus on organizational structure in an integrated manner with coordination and collaboration that ensure the execution of innovative culture. It is expected that evidence of this study will support the better-quality of management performance and suggest further studies that should investigate EO, FI and EM relationships in several contexts. Besides, this study contributed to the literature by emphasizing entrepreneurial orientation as a predictor to measure firm performance. Also, the current study is crosssectional but in the future it should be conducted longitudinal. Also, future research should be conducted under several environmental domains such as market turbulence and technological turbulence as an important antecedent of firm performance.

\section{References}

Al-Dhaafri, H. S., Al-Swidi, A. K., \& Yusoff, R. Z. B. (2016). The mediating role of total quality management between the entrepreneurial orientation and the organizational performance. The TQM Journal, 28(1), 89-111.

Anderson, B. S., Kreiser, P. M., Kuratko, D. F., Hornsby, J. S., \& Eshima, Y. (2015). Reconceptualizing entrepreneurial orientation. Strategic management journal, 36(10), 1579-1596.

Augusto, M., \& Coelho, F. (2009). Market orientation and new-to-the-world products: Exploring the moderating effects of innovativeness, competitive strength, and environmental forces. Industrial Marketing Management, 38(1), 94-108.

Barney, J. (1991). Firm resources and sustained competitive advantage. Journal of management, 17(1), 99-120.

Barney, J., Wright, M., \& Ketchen, D. J. (2001). The resource-based view of the firm: Ten years after 1991. Journal of management, 27(6), 625-641.

Barney, J. B., Ketchen, D. J., \& Wright, M. (2011). The future of resource-based theory revitalization or decline? Journal of management, 37(5), 1299-1315.

Barrows, E., \& Neely, A. (2011). Managing performance in turbulent times: analytics and insight: John Wiley \& Sons. 
Bedeian, A., \& Wren, D. (2009). The Evolution of Management Thought . Hoboken: NJ: John Wiley \& Sons, Inc.

Bhuian, S. N., Menguc, B., \& Bell, S. J. (2005). Just entrepreneurial enough: the moderating effect of entrepreneurship on the relationship between market orientation and performance. Journal of Business Research, 58(1), 9-17.

Calantone, R., Garcia, R., \& Dröge, C. (2003). The effects of environmental turbulence on new product development strategy planning. Journal of Product Innovation Management, 20(2), 90-103.

Chatman, J. A., \& Cha, S. E. (2003). Leading by leveraging culture. California Management Review, 45(4), $20-34$.

Covin, J. G., \& Lumpkin, G. T. (2011). Entrepreneurial orientation theory and research: Reflections on a needed construct. Entrepreneurship theory and practice, 35(5), 855-872.

Covin, J. G., \& Miller, D. (2014). International entrepreneurial orientation: conceptual considerations, research themes, measurement issues, and future research directions. Entrepreneurship theory and practice, 38(1), $11-44$.

Covin, J. G., \& Slevin, D. P. (1989). Strategic management of small firms in hostile and benign environments. Strategic management journal, 10(1), 75-87.

Covin, J. G., \& Wales, W. J. (2012). The measurement of entrepreneurial orientation. Entrepreneurship theory and practice, 36(4), 677-702.

Dada, O., \& Watson, A. (2013). Entrepreneurial orientation and the franchise system: Organisational antecedents and performance outcomes. European Journal of Marketing, 47(5/6), 790-812.

Damanpour, F. (1991). Organizational innovation: A meta-analysis of effects of determinants and moderators. Academy of management journal, 34(3), 555-590.

Danneels, E., \& Sethi, R. (2011). New product exploration under environmental turbulence. Organization Science, 22(4), 1026-1039.

De Clercq, D., Dimov, D., \& Thongpapanl, N. T. (2013). Organizational social capital, formalization, and internal knowledge sharing in entrepreneurial orientation formation. Entrepreneurship theory and practice, 37(3), 505-537.

Dibrell, C., Craig, J., \& Hansen, E. (2011). Natural environment, market orientation, and firm innovativeness: An organizational life cycle perspective. Journal of small business management, 49(3), 467-489.

Droge, C., Calantone, R., \& Harmancioglu, N. (2008). New product success: Is it really controllable by managers in highly turbulent environments? Journal of Product Innovation Management, 25(3), 272-286.

Eshima, Y., \& Anderson, B. S. (2016). Firm growth, adaptive capability, and entrepreneurial orientation. Strategic management journal.

Garcia, R., \& Calantone, R. (2002). A critical look at technological innovation typology and innovativeness terminology: a literature review. Journal of Product Innovation Management, 19(2), 110-132.

Han, J. K., Kim, N., \& Srivastava, R. K. (1998). Market orientation and organizational performance: is innovation a missing link? The Journal of Marketing, 30-45.

Hatch, M. with Cunliffe, AL (2006) Organization Theory-Modern, Symbolic and Postmodern Perspectives: Oxford: Oxford University Press.

Henard, D. H., \& Szymanski, D. M. (2001). Why some new products are more successful than others. Journal of marketing Research, 38(3), 362-375.

Hoegl, M., Parboteeah, K. P., \& Munson, C. L. (2003). Team-level antecedents of individuals' knowledge networks. Decision Sciences, 34(4), 741-770.

Hult, G. T. M., Hurley, R. F., \& Knight, G. A. (2004). Innovativeness: Its antecedents and impact on business performance. Industrial Marketing Management, 33(5), 429-438.

Hult, G. T. M., \& Ketchen, D. J. (2001). Does market orientation matter?: A test of the relationship between positional advantage and performance. Strategic management journal, 22(9), 899-906.

Hurley, R. F., \& Hult, G. T. M. (1998). Innovation, market orientation, and organizational learning: an integration and empirical examination. The Journal of Marketing, 42-54.

Jansen, J. J., Van Den Bosch, F. A., \& Volberda, H. W. (2006). Exploratory innovation, exploitative innovation, and performance: Effects of organizational antecedents and

Kemelgor, B. H. (2002). A comparative analysis of corporate entrepreneurial orientation between selected firms in the Netherlands and the USA. Entrepreneurship \& Regional Development, 14(1), 67-87.

Kipley, D., Lewis, A., \& Jewe, R. (2012). Entropy-disrupting Ansoff's five levels of environmental turbulence. Business Strategy Series, 13(6), 251-262.

Kirca, A. H., Jayachandran, S., \& Bearden, W. O. (2005). Market orientation: A meta-analytic review and assessment of its antecedents and impact on performance. Journal of marketing, 69(2), 24-41.

Kraaijenbrink, J., Spender, J.-C., \& Groen, A. J. (2010). The resource-based view: a review and assessment of its critiques. Journal of management, 36(1), 349-372. 
Kraus, S., Rigtering, J. C., Hughes, M., \& Hosman, V. (2012). Entrepreneurial orientation and the business performance of SMEs: a quantitative study from the Netherlands. Review of Managerial Science, 6(2), 161182.

Lee, S. M., Lim, S.-b., \& Pathak, R. D. (2011). Culture and entrepreneurial orientation: a multi-country study. International Entrepreneurship and Management Journal, 7(1), 1-15.

Li, Zhang, Y., \& Chan, T.-S. (2005). Entrepreneurial strategy making and performance in China's new technology ventures-the contingency effect of environments and firm competences. The Journal of High Technology Management Research, 16(1), 37-57.

Li, Y.-H., Huang, J.-W., \& Tsai, M.-T. (2009). Entrepreneurial orientation and firm performance: The role of knowledge creation process. Industrial Marketing Management, 38(4), 440-449.

Luk, C.-L., Yau, O. H., Sin, L. Y., Tse, A. C., Chow, R. P., \& Lee, J. S. (2008). The effects of social capital and organizational innovativeness in different institutional contexts. Journal of International Business Studies, 39(4), 589-612.

Lumpkin, \& Dess, G. G. (1996). Clarifying the entrepreneurial orientation construct and linking it to performance. Academy of management Review, 21(1), 135-172.

Lumpkin, \& Dess, G. G. (2001). Linking two dimensions of entrepreneurial orientation to firm performance: The moderating role of environment and industry life cycle. Journal of business venturing, 16(5), 429-451.

Lumpkin, \& Dess, G. G. (2005). Entrepreneurial orientation. Wiley Encyclopedia of Management.

Marcati, A., Guido, G., \& Peluso, A. M. (2008). The role of SME entrepreneurs' innovativeness and personality in the adoption of innovations. Research Policy, 37(9), 1579-1590.

Mason, M. C., Floreani, J., Miani, S., Beltrame, F., \& Cappelletto, R. (2015). Understanding the Impact of Entrepreneurial Orientation on Smes' Performance. the Role of the Financing Structure. Procedia Economics and Finance, 23, 1649-1661.

Mason, M. C., \& Gos, L. (2014). The role of agglomeration in entrepreneurship: empirical evidence from Italy. International Journal of Entrepreneurship and Small Business, 21(1), 33-54.

Menguc, B., \& Auh, S. (2006). Creating a firm-level dynamic capability through capitalizing on market orientation and innovativeness. Journal of the academy of marketing science, 34(1), 63-73.

Miller, D. (1983). The correlates of entrepreneurship in three types of firms. Management science, 29(7), 770-791.

Miller, D. (2011). Miller (1983) revisited: A reflection on EO research and some suggestions for the future. Entrepreneurship theory and practice, 35(5), 873-894.

Miller, D., \& Shamsie, J. (1996). The resource-based view of the firm in two environments: The Hollywood film studios from 1936 to 1965. Academy of management journal, 39(3), 519-543.

Nasution, H. N., Mavondo, F. T., Matanda, M. J., \& Ndubisi, N. O. (2011). Entrepreneurship: Its relationship with market orientation and learning orientation and as antecedents to innovation and customer value. Industrial Marketing Management, 40(3), 336-345.

Northouse, P. G. (2015). Leadership: Theory and practice: Sage publications.

Rauch, A., Wiklund, J., Lumpkin, G. T., \& Frese, M. (2009). Entrepreneurial orientation and business performance: An assessment of past research and suggestions for the future. Entrepreneurship theory and practice, 33(3), 761-787.

Shan, P., Song, M., \& Ju, X. (2016). Entrepreneurial orientation and performance: Is innovation speed a missing link? Journal of Business Research, 69(2), 683-690.

Tajeddini, K., Trueman, M., \& Larsen, G. (2006). Examining the effect of market orientation on innovativeness. Journal of marketing management, 22(5-6), 529-551.

Tang, Z., \& Tang, J. (2012). Entrepreneurial orientation and SME performance in China's changing environment: The moderating effects of strategies. Asia Pacific Journal of Management, 29(2), 409-431.

Tellis, G. J., Prabhu, J. C., \& Chandy, R. K. (2009). Radical innovation across nations: The preeminence of corporate culture. Journal of marketing, 73(1), 3-23.

Tidd, J. (2001). Innovation management in context: environment, organization and performance. International Journal of Management Reviews, 3(3), 169-183.

Tsai, K.-H., Chou, C., \& Kuo, J.-H. (2008). The curvilinear relationships between responsive and proactive market orientations and new product performance: A contingent link. Industrial Marketing Management, 37(8), 884894.

Tsai, K.-H., \& Yang, S.-Y. (2013). Firm innovativeness and business performance: The joint moderating effects of market turbulence and competition. Industrial Marketing Management, 42(8), 1279-1294.

Tsai, K.-H., \& Yang, S.-Y. (2014). The contingent value of firm innovativeness for business performance under environmental turbulence. International Entrepreneurship and Management Journal, 10(2), 343-366. 
Wales, W. J. (2016). Entrepreneurial orientation: A review and synthesis of promising research directions. International Small Business Journal, 34(1), 3-15.

Wales, W. J., Parida, V., \& Patel, P. C. (2013). Too much of a good thing? Absorptive capacity, firm performance, and the moderating role of entrepreneurial orientation. Strategic management journal, 34(5), 622-633.

Wales, W. J., Patel, P. C., \& Lumpkin, G. (2013). In pursuit of greatness: CEO narcissism, entrepreneurial orientation, and firm performance variance. Journal of Management Studies, 50(6), 1041-1069.

Walter, A., Auer, M., \& Ritter, T. (2006). The impact of network capabilities and entrepreneurial orientation on university spin-off performance. Journal of business venturing, 21(4), 541-567.

Wang, H.-K., \& Yen, Y.-F. (2012). An empirical exploration of corporate entrepreneurial orientation and performance in Taiwanese SMEs: A perspective of multidimensional construct. Total Quality Management \& Business Excellence, 23(9-10), 1035-1044.

Wiklund, J., \& Shepherd, D. (2003). Knowledge-based resources, entrepreneurial orientation, and the performance of small and medium-sized businesses. Strategic management journal, 24(13), 1307-1314.

Yildiz, S. (2010). A study on measuring business performance in banking sector. Erciyes University, Faculty of Economy and Administrative Sciences Journal, 36, 179-193.

Yıldız, S., \& Karakaş, A. (2012). Defining methods and criteria for measuring business performance: a comparative research between the literature in Turkey and foreign. Procedia-Social and Behavioral Sciences, 58, 10911102.

Zahra, S. A., \& Covin, J. G. (1995). Contextual influences on the corporate entrepreneurship-performance relationship: A longitudinal analysis. Journal of business venturing, 10(1), 43-58.

Zahra, S. A., \& Wright, M. (2011). Entrepreneurship's next act. The Academy of Management Perspectives, 25(4), 6783.

Zhang, J. A., Edgar, F., Geare, A., \& O'Kane, C. (2016). The interactive effects of entrepreneurial orientation and capability-based HRM on firm performance: The mediating role of innovation ambidexterity. Industrial Marketing Management.

Zhang, Y., \& Zhang, X. e. (2012). The effect of entrepreneurial orientation on business performance: A role of network capabilities in China. Journal of Chinese Entrepreneurship, 4(2), 132-142. 